\title{
POTENSI AIR TANAH DANGKAL DI DAERAH KELURAHAN KOTA BARU KECAMATAN PONTIANAK SELATAN - KOTA PONTIANAK (Studi Kasus Jalan Dr. Sutomo - Ampera)
}

\author{
Astra Wijaya ${ }^{1}$, Marsudi ${ }^{2}$, Robby Irsan ${ }^{1}$ \\ ${ }^{1}$ Program Studi Teknik Lingkungan, Universitas Tanjungpura, Pontianak \\ ${ }^{2}$ Program Studi Teknik Sipil, Universitas Tanjungpura, Pontianak \\ email: astra adreaz@yahoo.com
}

\begin{abstract}
ABSTRAK
Daerah Kota Baru, Kelurahan Kota Baru, Kecamatan Pontianak Selatan, Kota Pontianak, tepatnya di jalan Dr. Sutomo sampai jalan Ampera merupakan daerah pemukiman serta perdagangan yang sering mengalami kekurangan air bersih terutama pada musim kemarau. Daerah tersebut sebenarnya sudah terjangkau oleh jaringan Perusahaan Daerah Air Minum (PDAM) namun jumlah air masih terbatas dan kualitas masih kurang baik hanya melayani 78.194 pelanggan dengan cakupan $74,1 \%$ penduduk (Perusahaan Daerah Air Minum Kota Pontianak, 2012). Salah satu upaya yang dilakukan untuk mengatasi kekurangan air baku adalah dengan memanfaatkan sumber air tanah bebas sebagai sumber air baku. Penelitian bertujuan untuk mengetahui kuantitas air menurut Kepmen Energi dan SDM No.1451/10/MEM/2000, kualitas air berdasarkan PP No.82 Tahun 2001 kelas I serta arah aliran/pola sebaran didaerah penelitian. Pengukuran tinggi muka air tanah dan pengambilan sampel air tanah pada waktu sebelum hujan/kemarau pada tanggal 3 Februari 2014 dan setelah hujan pada tanggal 1 Maret 2014. Sumur yang dipilih sebanyak 12 titik untuk pengukuran tinggi muka air tanah serta kuantitas air di daerah penelitian sedangkan uji kualitas dipilih 4 sumur dengan metode pengambilan sampel menggunakan grab sampel. Parameter yang di uji adalah TSS, TDS, Besi (Fe), pH, Sulfat $\left(\mathrm{SO}_{4}\right)$ dan $\mathrm{BOD}_{5}$. Kuantitas air tanah sebelum hujan untuk debit maksimum 0,003645 I/detik sedangkan setelah hujan debit maksimum sebesar 0,004062 l/detik. Hasil ini menunjukkan bahwa kuantitas air tanah bebas di daerah tersebut masuk kedalam kategori potensi kecil karena berada $<2$ liter/detik. Analisis kualitas air sumur parameter TSS tertinggi sebelum hujan $89 \mathrm{mg} / \mathrm{l}$ dan terendah $11 \mathrm{mg} / \mathrm{l}$ sedangkan nilai tertinggi setelah hujan $73 \mathrm{mg} / \mathrm{l}$ dan terendah $3 \mathrm{mg} / \mathrm{l}$. Nilai TDS tertinggi sebelum hujan $742 \mathrm{mg} / \mathrm{l}$ dan terendah $189,9 \mathrm{mg} / \mathrm{l}$ sedangkan nilai tertinggi setelah hujan $1148 \mathrm{mg} / \mathrm{l}$ dan terendah $213 \mathrm{mg} / \mathrm{l}$. Nilai Besi (Fe) tertinggi sebelum hujan $9,294 \mathrm{mg} / \mathrm{l}$ dan terendah $0,896 \mathrm{mg} / \mathrm{l}$ sedangkan nilai tertinggi setelah hujan $0,306 \mathrm{mg} / \mathrm{l}$ dan terendah $0,034 \mathrm{mg} / \mathrm{l}$. Nilai $\mathrm{pH}$ tertinggi sebelum hujan sebesar 7,25 dan terendah 6,82 sedangkan nilai tertinggi setelah hujan 6,93 dan terendah 6,142. Nilai Sulfat $\left(\mathrm{SO}_{4}\right)$ tertinggi sebelum hujan $32 \mathrm{mg} / \mathrm{l}$ dan terendah $0 \mathrm{mg} / \mathrm{l}$ sedangkan nilai tertinggi setelah hujan $77 \mathrm{mg} / \mathrm{l}$ dan terendah 25 $\mathrm{mg} / \mathrm{l}$. Nilai BOD tertinggi sebelum hujan $135,59 \mathrm{mg} / \mathrm{l}$ dan terendah $17,28 \mathrm{mg} / \mathrm{l}$ sedangkan nilai tertinggi setelah hujan 24,91 dan terendah $12,2 \mathrm{mg} / \mathrm{l}$. Hasil uji kualitas air tanah menunjukkan tidak layak untuk digunakan untuk air baku air minum dan/atau peruntukan lainnya karena masih terdapat parameter yang berada di atas baku mutu. Pola aliran air tanah di daerah penelitian mengalir dari arah selatan menuju ke arah utara yaitu bermuara ke sungai kapuas. Pola sebaran parameter pencemar mengikuti arah arah aliran air tanah dan dipengaruhi oleh aktivitas yang ada disekitar lokasi sumur.
\end{abstract}

Kata Kunci : Air Tanah, Kuantitas air tanah, Kualitas air tanah, arah aliran, pola sebaran parameter pencemar. 


\begin{abstract}
Kota Baru area, Kelurahan Kota Baru, Kecamatan Pontianak Selatan, Pontianak City, started from Jalan Dr. Sutomo until Jalan Ampera is a living and trading area in which there is a frequent shortage of clean water supply, especially on dry season. Actually, clean water for this area has been supplied by Perusahaan Daerah Air Minum (PDAM), but there is still a limit amount of the water and a lack of its quality. The service can only reach up to 78,194 customers or up to $74.1 \%$ of the people (Perusahaan Air Minum Kota Pontianak, 2012). One of the efforts to overcome shortage of water sources is by utilizing sources of ground water as water sources. This research aimed at finding out the water quantity based on Kepmen Energi dan SDM No. 1451/01/MEM/2000, water quality based on PP. No.82 Tahun 2001 kelas 1, and the flow direction/the dissemination pattern in this researched area.

The measurement of the height of water table and the sampling of the ground water was done before rain on a dry season, on February, 32014 and after rain on a dry season, on March 1, 2014. 12 wells were chosen to measure the height of the water table and the water quantity. Meanwhile, to test the water quality, the researcher chose 4 wells by using grab sampling method. The parameters which were tested were TSS, TDS, $\mathrm{Fe}, \mathrm{pH}$, Sulfat $\left(\mathrm{SO}_{4}\right)$, and $\mathrm{BOD}$.

The water quantity before rain for maximum debit was $0.003645 \mathrm{l} / \mathrm{second}$, while after rain the maximum debit became $0.004062 \mathrm{l} / \mathrm{second}$. This finding showed that the groundwater quantity in this area was categorized as potentially limited in which it was $<2$ litre/second. The analysis of well water quality by using TSS parameter before rain was $89 \mathrm{mg} / \mathrm{l}$ for the highest and $11 \mathrm{mg} / \mathrm{l}$ for the lowest. Meanwhile, after rain, the highest point was $73 \mathrm{mg} / \mathrm{l}$ and the lowest was $3 \mathrm{mg} / \mathrm{l}$. The highest TDS, before rain, was $742 \mathrm{mg} / \mathrm{l}$ and the lowest was $189.9 \mathrm{mg} / \mathrm{l}$, while the highest TDS after rain was $1148 \mathrm{mg} / \mathrm{l}$ and the lowest was $213 \mathrm{mg} / \mathrm{l}$. The highest Fe, before rain, was $9.294 \mathrm{mg} / \mathrm{l}$ and the lowest was $0.896 \mathrm{mg} / \mathrm{l}$, while the highest after rain was $0,306 \mathrm{mg} / \mathrm{l}$ and the lowest was $0,034 \mathrm{mg} / \mathrm{l}$. The highest $\mathrm{pH}$, before rain, was 7,25 and the lowest was 6.82, while the highest after rain was 6.93 and the lowest was 6.142. The highest Sulfat $\left(\mathrm{SO}_{4}\right)$, before rain, was $32 \mathrm{mg} / \mathrm{l}$ and the lowest was $0 \mathrm{mg} / \mathrm{l}$, while the highest after rain was 77 $\mathrm{mg} / \mathrm{l}$ and the lowest was $25 \mathrm{mg} / \mathrm{l}$ and The highest BOD before rain, was $135.59 \mathrm{mg} / \mathrm{l}$ and the lowest was $17.28 \mathrm{mg} / \mathrm{l}$, while the highest after rain was $24.91 \mathrm{mg} / \mathrm{l}$ and the lowest was $12.2 \mathrm{mg} / \mathrm{l}$. From this finding, it was revealed that the quality of the groundwater was not good to use as water sources, drinking water, and/or for other usages because some parameters were still above the standard quality. The flow pattern of the groundwater in this researched area was that it flowed from the south to the north which was to Kapuas estuary. The dissemination pattern of pollutant parameters went with the flow of the groundwater and was influenced by activities occurred around the wells.
\end{abstract}

Keywords : Groundwater, Ground water Quantity, Ground water quality, flow of the groundwater The dissemination pattern of pollutant parameters. 


\section{PENDAHULUAN}

Di Kota Pontianak, ketersediaan air baku untuk air bersih, pertanian, industri dan lain sebagainya masih terbatas. Hal ini semakin diperparah dengan tidak tersedianya air permukaan dengan kualitas yang memadai. Kekurangan air ini makin terasa terutama pada saat musim kemarau, dimana instrusi air laut (asin) memasuki sungai jauh ke arah daratan sehingga menganggu pemanfaatan air sungai (air permukaan). Kekurangan air pada musim kemarau, juga sangat dirasakan oleh Perusahaan Daerah Air Minum (PDAM) karena sulitnya mendapatkan sumber air baku akibat air sungai Kapuas mengalami instrusi air laut.

Pada penulisan skripsi ini, penulis memilih daerah Kota Baru, Kelurahan Kota Baru, Kecamatan Pontianak Selatan, Kota Pontianak, tepatnya di jalan Dr. Sutomo sampai jalan Ampera sebagai lokasi penelitian karena daerah tersebut merupakan daerah pemukiman serta perdagangan yang sering mengalami kekurangan air terutama pada musim kemarau. Daerah tersebut sebenarnya sudah terjangkau oleh jaringan Perusahaan Daerah Air Minum (PDAM) namun jumlah air masih terbatas dan kualitas masih kurang baik.

Salah satu upaya yang dilakukan untuk mengatasi kekurangan air baku adalah dengan memanfaatkan sumber air tanah bebas sebagai penyedia air baku. Pengembangan pemanfaatan air tanah didahului dengan eksplorasi air tanah berupa survey hidrogeologi. Ketersediaan air tanah ditentukan oleh beberapa faktor penting, yaitu klimatologi, geomorfologi dan kondisi geologi serta penyebaran akuifer yang ada di suatu daerah. Selain itu, pengujian kualitas air tanah harus dilakukan.

\section{METODOLOGI PENELITIAN}

Penelitian ini berlokasi di daerah Kota Baru, Kelurahan Kota Baru, Kecamatan Pontianak Selatan Kota Pontianak, tepatnya di jalan Dr. Sutomo sampai jalan Ampera. Pengambilan sampel air sumur serta pengukuran tinggi muka air tanah dilakukan pada saat sebelum hujan dan setelah hujan, bulan Desember 2013 dengan tahap penelitian yaitu :

a. Tahap persiapan yaitu berupa pengumpulan referensi dari berbagai literatur yang meliputi jurnal, skripsi dan buku yang berkenaan dengan potensi air tanah bebas dan kualitas air.

b. Tahap pengumpulan data berupa data primer dan data sekunder. Data sekunder yang dikumpulkan dalam penelitian ini berupa data topografi daerah kota baru, kecamatan pontianak selatan, kota pontianak yang didapatkan dari instansi-instansi yang terkait. Sedangkan data primer yang dikumpulkan berupa data tinggi muka air tanah dan data kualitas air dari hasil pengujian di laboratorium.

c. Tahap Penelitian yaitu menentukan titik lokasi pengamatan (titik sampling air), pengukuran tinggi muka air tanah, membuat peta tinggi muka air tanah, membuat pola sebaran zat pencemar, menghitung luas daerah penelitian, menghitung debit air tanah bebas dan pengambilan sampel kualitas air.

d. Analisa kuantitas air tanah. Proses analisa kuantitas air tanah yaitu dengan membandingkan data hasil perhitungan dengan kriteria kuantitas air tanah berdasarkan Keputusan Menteri Energi dan Sumber Daya Mineral Nomor 1451/10/MEM/2000 dalam bentuk table, melakukan analisis kebutuhan air bersih setiap kepala keluarga untuk melihat jumlah kepala keluarga yang terlayani berdasarkan debit yang tersedia.

e. Analisa kualitas air. Proses analisa kualitas air yaitu dengan membandingkan data hasil pengujian di laboratorium dengan baku mutu kualitas air menurut Peraturan Pemerintah No.82 tahun 2001 tentang Pengelolaan Kualitas Air dan Pengendalian Pencemaran Air dalam bentuk tabel. 


\section{HASIL DAN ANALISA}

\section{A. Hasil Pengukuran Tinggi Muka Air Tanah}

Pengukuran tinggi muka air tanah dilakukan di 12 titik sampel sumur daerah penelitian. Pengukuran dilakukan pada saat sebelum hujan dan setelah hujan. Pengukuran tinggi muka air tanah dilakukan dengan menggunakan meteran untuk mengetahui perbedaan tinggi muka tanah dengan muka air. Pengukuran ini digunakan untuk menghitung debit air sumur. Data tinggi muka air tanah sebelum hujan dan setelah hujan dapat dilihat pada Tabel 1 dan Tabel 2 berikut :

Tabel 1. Data Tinggi Muka Air Tanah Sebelum Hujan

\begin{tabular}{|c|c|c|c|c|c|}
\hline No & $\begin{array}{c}\text { Titik } \\
\text { Sumur }\end{array}$ & $\begin{array}{c}\text { Elevasi } \\
(\mathbf{m})\end{array}$ & $\begin{array}{c}\text { Tinggi Muka Air } \\
\text { Sebelum Hujan }(\mathbf{m})\end{array}$ & $\begin{array}{c}\text { Elevasi Tinggi } \\
\text { Muka Air }(\mathbf{m})\end{array}$ & Cuaca \\
\hline $\mathbf{1}$ & W1 & 2 & 0,81 & 1,19 & Cerah \\
$\mathbf{2}$ & W2 & 2 & 0,71 & 1,29 & Cerah \\
$\mathbf{3}$ & W3 & 2 & 0,8 & 1,20 & Cerah \\
$\mathbf{4}$ & W4 & 3 & 1,01 & 1,99 & Cerah \\
$\mathbf{5}$ & W5 & 3 & 0,93 & 2,07 & Cerah \\
$\mathbf{6}$ & W6 & 3 & 1,69 & 1,31 & Cerah \\
$\mathbf{7}$ & W7 & 3 & 0,64 & 2,36 & Cerah \\
$\mathbf{8}$ & W8 & 3 & 0,51 & 2,49 & Cerah \\
$\mathbf{9}$ & W9 & 4 & 1,02 & 2,98 & Cerah \\
$\mathbf{1 0}$ & W10 & 4 & 1,00 & 3,00 & Cerah \\
$\mathbf{1 1}$ & W11 & 4 & 0,95 & 3,05 & Cerah \\
$\mathbf{1 2}$ & W12 & 4 & 0,92 & 3,08 & Cerah \\
\hline
\end{tabular}

Berdasarkan hasil pengukuran tinggi muka air tanah sebelum hujan di ambil titik sumur untuk perhitungan debit air dengan landaian hidrolika terendah yaitu titik W2 dan W11 sedangkan untuk debit maksimum diambil dengan landaian hidrolika terendah yaitu titik W10 dan W3.

Tabel 2. Data Tinggi Muka Air Tanah Sebelum Hujan

\begin{tabular}{|c|c|c|c|c|c|}
\hline No & $\begin{array}{c}\text { Titik } \\
\text { Sumur }\end{array}$ & $\begin{array}{c}\text { Elevasi } \\
(\mathbf{m})\end{array}$ & $\begin{array}{c}\text { Tinggi Muka Air } \\
\text { Setelah Hujan }(\mathbf{m})\end{array}$ & $\begin{array}{c}\text { Elevasi Tinggi } \\
\text { Muka Air (m) }\end{array}$ & Cuaca \\
\hline $\mathbf{1}$ & W1 & 2 & 0,72 & 1,28 & Cerah \\
$\mathbf{2}$ & W2 & 2 & 0,57 & 1,43 & Cerah \\
$\mathbf{3}$ & W3 & 2 & 0,50 & 1,50 & Cerah \\
$\mathbf{4}$ & W4 & 3 & 0,88 & 2,12 & Cerah \\
$\mathbf{5}$ & W5 & 3 & 0,81 & 2,19 & Cerah \\
$\mathbf{6}$ & W6 & 3 & 1,48 & 1,52 & Cerah \\
$\mathbf{7}$ & W7 & 3 & 0,49 & 2,51 & Cerah \\
$\mathbf{8}$ & W8 & 3 & 0,44 & 2,56 & Cerah \\
$\mathbf{9}$ & W9 & 4 & 0,82 & 3,18 & Cerah \\
$\mathbf{1 0}$ & W10 & 4 & 0,87 & 3,13 & Cerah \\
$\mathbf{1 1}$ & W11 & 4 & 0,76 & 3,24 & Cerah \\
$\mathbf{1 2}$ & W12 & 4 & 0,71 & 3,29 & Cerah \\
\hline
\end{tabular}

Berdasarkan hasil pengukuran tinggi muka air tanah setelah hujan di ambil titik sumur untuk perhitungan debit air dengan landaian hidrolika terendah yaitu titik W10 dan W3 sedangkan untuk debit maksimum diambil dengan landaian hidrolika terendah yaitu titik W12 dan W1. 
B. Kuantitas Air Tanah Sebelum Hujan

Debit Minimum

$$
\begin{aligned}
& \text { Diketahui } \quad: \quad \mathrm{K}=0,0002 \mathrm{m3} / \text { hari } \\
& \mathrm{i}=\frac{d h}{d l}=\frac{3,05-1,29}{1900 \mathrm{~m}}=0,000926 \\
& A=1576294,62 \mathrm{~m}^{2} \\
& \text { Ditanyakan : } \mathrm{Q}=\ldots \text { ? } \\
& \text { Penyelesaian : } Q=K . \mathrm{i} . \mathrm{A} \\
& =0,0002 \mathrm{~m} / \text { hari } .0,000926.1576294,62 \mathrm{~m}^{2} \\
& =0,291 \mathrm{~m}^{3} / \text { hari } \\
& =0,003368 \mathrm{l} / \text { detik }
\end{aligned}
$$

Debit Maksimum

$$
\text { Diketahui } \quad \begin{aligned}
\mathrm{K} & =0,0002 \mathrm{~m} 3 / \text { hari } \\
\mathrm{i} & =\frac{d h}{d l}=\frac{3,00-1,2}{1800 \mathrm{~m}}=0,001 \\
\text { Ditanyakan } \quad: \quad \mathrm{Q} & =\ldots \text { ? } \\
\text { Penyelesaian } \quad: \quad \mathrm{Q} & =\mathrm{K} . \mathrm{i} . \mathrm{A} \\
& =0,0002 \mathrm{~m} / \text { hari } .0,001.1576294,62 \\
& =0,315 \mathrm{~m}^{3} / \text { hari } \\
& =0,003645 \mathrm{l} / \text { detik }
\end{aligned}
$$

\section{Debit Rata-rata}

Q Rata-rata

$$
\begin{aligned}
& =\frac{Q \text { Maksimum }+Q \text { Minimum }}{2} \\
& =\frac{0,003645 \mathrm{l} / \mathrm{detik}+0,003368 \mathrm{l} / \text { detik }}{2} \\
& =0,003506 \mathrm{l} / \mathrm{detik}
\end{aligned}
$$

\section{Kuantitas Air Tanah Setelah Hujan}

\section{Debit Minimum}

Diketahui

$$
\begin{aligned}
\mathrm{K} & =\mathrm{m} 3 / \text { hari } \\
\mathrm{I} & =\frac{d h}{d l}=\frac{3,13-1,5}{1800}=0,000905 \\
\mathrm{~A} & =1576294,62 \mathrm{~m}^{2} \\
\mathrm{Q} & =\ldots ? \\
\mathrm{Q} & =\mathrm{K} \cdot \mathrm{i} \cdot \mathrm{A} \\
& =0,0002 \mathrm{~m} / \text { hari } .0,000905.1576294,62 \\
& =0,285 \mathrm{~m}^{3} / \text { hari } \\
& =0,003298 \mathrm{l} \text { /detik }
\end{aligned}
$$

Ditanyakan

Penyelesaian

Debit Maksimum

Diketahui

$$
\begin{aligned}
& \mathrm{K}=0,0002 \mathrm{~m} 3 / \text { hari } \\
& \mathrm{i}=\frac{d h}{d l}=\frac{3,29-1,28}{1800 \mathrm{~m}}=0,001116 \\
& A=1576294,62 \mathrm{~m}^{2} \\
& \text { Ditanyakan : } \mathrm{Q}=\ldots \text { ? } \\
& =0,0002 \mathrm{~m} / \text { hari } \cdot 0,001116 \cdot 1576294,62 \\
& =0,351 \mathrm{~m}^{3} / \text { hari } \\
& =0,004062 \mathrm{l} / \text { detik }
\end{aligned}
$$$$
\text { Penyelesaian : } \mathrm{Q}=\mathrm{K} . \mathrm{i} . \mathrm{A}
$$ 


\section{Debit Rata-rata}

Q Rata-rata

$$
\begin{aligned}
& =\frac{Q \text { Maksimum }+Q \text { Minimum }}{2} \\
& =\frac{0,004062 \mathrm{l} / \text { detik }+0,003298 \mathrm{l} / \text { detik }}{2} \\
& =0,00368 \mathrm{l} / \text { detik }
\end{aligned}
$$

Berdasarkan hasil perhitungan di atas kuantitas air sebelum hujan debit minimum $0,003368 \mathrm{l} /$ detik, debit maksimum $0,003645 \mathrm{l} /$ detik, debit rata-rata $0,003506 \mathrm{l} /$ detik. Kuantitas air setelah hujan debit minimum I/detik, debit maksimum 0,004062 l/detik, debit rata-rata 0,00368 1/detik, maka sesuai Keputusan Menteri Energi dan Sumber Daya Mineral Nomor 1451/10/MEM/2000, sumber air baku (sumur) di daerah Kota Baru, Kelurahan Kota Baru, Kecamatan Pontianak Selatan, Kota Pontianak, tepatnya di jalan Dr. Sutomo sampai jalan Ampera masuk dalam daerah dengan kategori kuantitas air kecil (debit air $(\mathrm{Q})<2 \mathrm{l} / \mathrm{det}$ ).

\section{Analisa Kualitas Air}

\section{- TSS (Total Suspended Solid)}

TSS atau padatan tersuspensi total adalah bahan tersuspensi dengan diameter $>1 \mu \mathrm{m}$ yang tertahan pada saringan miliphore berdiameter pori 0,45 $\mu \mathrm{m}$ sebagai sisa hasil penguapan dan pemanasan pada suhu 103-105C (Saeni, 1989). Hasil pengujian kualitas air untuk

\begin{tabular}{|c|c|c|c|c|c|c|c|}
\hline \multirow[t]{2}{*}{ No } & \multirow[t]{2}{*}{$\begin{array}{l}\text { Titik } \\
\text { Sumur }\end{array}$} & $\begin{array}{c}\text { PP No.82 } \\
\text { Tahun } \\
2001 \\
\end{array}$ & \multirow[t]{2}{*}{ Satuan } & \multirow[t]{2}{*}{$\begin{array}{l}\text { Sebelum } \\
\text { Hujan }\end{array}$} & \multirow[t]{2}{*}{ Ket } & \multirow[t]{2}{*}{$\begin{array}{c}\text { Setelah } \\
\text { Hujan }\end{array}$} & \multirow[t]{2}{*}{ Ket } \\
\hline & & Kelas 1 & & & & & \\
\hline 1 & w2 & 50 & $\mathrm{mg} / \mathrm{l}$ & 52 & Tidak Layak & 21 & Layak \\
\hline 2 & W4 & 50 & $\mathrm{mg} / \mathrm{l}$ & 11 & Layak & 3 & Layak \\
\hline 3 & W7 & 50 & $\mathrm{mg} / \mathrm{l}$ & 60 & Tidak Layak & 29 & Layak \\
\hline 4 & W10 & 50 & $\mathrm{mg} / \mathrm{l}$ & 89 & Tidak Layak & 73 & Tidak Layak \\
\hline
\end{tabular}
parameter TSS dapat dilihat pada Tabel 3 berikut :

Tabel 3. Hasil Analisa Kualitas Air Sumur Parameter TSS

Berdasarkan data pengukuran TSS pada tabel 5, diketahui untuk sampel air sumur yang diambil sebelum hujan, nilai TSS dari 3 titik sumur, yaitu W2, W7 dan W10 melebihi ambang batas kualitas air baku, sedangkan untuk nilai TSS sampel air sumur yang diambil setelah hujan, hanya 1 titik sumur, yaitu W10 yang melebihi ambang batas kualitas air baku.

\section{- $\quad$ TDS (Total Disolved Solid)}

Total padatan terlarut merupakan bahan-bahan terlarut dalam air yang tidak tersaring dengan kertas saring millipore dengan ukuran pori 0,45 $\mu \mathrm{m}$. Padatan ini terdiri dari senyawasenyawa anorganik dan organik yang terlarut dalam air, mineral dan garam-garamnya (Effendi, 2003). Hasil pengujian kualitas air untuk parameter TDS dapat dilihat pada Tabel 4 berikut : 
Tabel 4. Hasil Analisa Kualitas Air Sumur Parameter TDS

\begin{tabular}{|c|c|c|c|c|c|c|c|}
\hline \multirow[t]{2}{*}{ No } & \multirow[t]{2}{*}{ Sumur } & $\begin{array}{c}\text { PP No.82 } \\
\text { Tahun } \\
2001 \\
\end{array}$ & \multirow[t]{2}{*}{ Satuan } & \multirow[t]{2}{*}{$\begin{array}{c}\text { Sebelum } \\
\text { Hujan }\end{array}$} & \multirow[t]{2}{*}{ Ket } & \multirow[t]{2}{*}{$\begin{array}{c}\text { Setelah } \\
\text { Hujan }\end{array}$} & \multirow[t]{2}{*}{ Ket } \\
\hline & & Kelas 1 & & & & & \\
\hline 1 & w2 & 1000 & $\mathrm{mg} / \mathrm{l}$ & 375 & Layak & 1148 & Tidak Layak \\
\hline 2 & W4 & 1000 & $\mathrm{mg} / \mathrm{l}$ & 189,9 & Layak & 213 & Layak \\
\hline 3 & W7 & 1000 & $\mathrm{mg} / \mathrm{l}$ & 742 & Layak & 645 & Layak \\
\hline 4 & W10 & 1000 & $\mathrm{mg} / \mathrm{l}$ & 603 & Layak & 528 & Layak \\
\hline
\end{tabular}

Berdasarkan hasil pengujian kualitas air sumur sebelum hujan menunjukan semua sumur memiliki kandungan TDS berada dibawah baku mutu. Sedangkan hasil pengujian kualitas air sumur setelah hujan Sumur W2 berada di atas baku mutu di sebabkan karena sumur tersebut terletak dekat dengan aktivitas jasa pencucian motor dimana air yang terkandung dalam pencucian tersebut mengandung sabun dan deterjen. Air buangan tersebut meresap kedalam sumur dan larut dalam air.

\section{- $\quad$ Besi (Fe)}

Besi adalah salah satu elemen yang dapat ditemui hampir pada setiap tempat di bumi, pada semua lapisan geologis dan semua badan air. Pada umumnya besi yang ada di dalam air dapat bersifat terlarut sebagai Fe 2+ atau Fe3+. Hasil pengujian kualitas air untuk parameter Besi (Fe) dapat dilihat pada Tabel 5 berikut :

Tabel 5. Hasil Analisa Kualitas Air Sumur Parameter Besi (Fe)

\begin{tabular}{|c|c|c|c|c|c|c|c|}
\hline \multirow{2}{*}{ No } & \multirow{2}{*}{ Sumur } & $\begin{array}{c}\text { PP No.82 } \\
\text { Tahun } \\
\mathbf{2 0 0 1}\end{array}$ & \multirow{2}{*}{ Satuan } & $\begin{array}{c}\text { Sebelum } \\
\text { Hujan }\end{array}$ & Ket & $\begin{array}{c}\text { Setelah } \\
\text { Hujan }\end{array}$ & Ket \\
\cline { 3 - 6 } & Kelas 1 & & Tidak Layak & 0,247 & Layak \\
\hline 1 & W2 & 0,3 & $\mathrm{mg} / \mathrm{l}$ & 1,798 & Tayak \\
2 & W4 & 0,3 & $\mathrm{mg} / \mathrm{l}$ & 0,896 & Tidak Layak & 0,034 & Layak \\
3 & W7 & 0,3 & $\mathrm{mg} / \mathrm{l}$ & 9,294 & Tidak Layak & 0,306 & Layak \\
4 & W10 & 0,3 & $\mathrm{mg} / \mathrm{l}$ & 7,69 & Tidak Layak & 0,280 & Layak \\
\hline
\end{tabular}

Berdasarkan hasil pengujian sebelum hujan menunjukan bahwa semua sumur yang di uji memiliki kandungan besi berada diatas ambang batas maksimum diperbolehkan dengan baku mutu kelas I. sumur pertama sebesar $1,798 \mathrm{mg} / \mathrm{I}$ sebelum hujan dan $0,247 \mathrm{mg} / \mathrm{l}$ setelah hujan. Tingginya nilai Fe dimungkinkan karena adanya proses reduksi yaitu ferri (Fe3+) dengan sifat sukar larut dalam air menjadi ferro $(\mathrm{Fe} 2+)$ larut dalam air. Sumber Fe diperkirakan secara alamiah yaitu dari lapisan tanah, mengingat dilokasi penelitian tidak ada limbah industri sebagai sumber Fe buatan. Pada sumur kedua nilai besi (Fe) sebelum hujan sebesar 0,896 mg/l dan $0,034 \mathrm{mg} / \mathrm{l}$. Untuk nilai besi (Fe) sebelum hujan berada di atas baku mutu, hal ini dapat dilihat dengan kondisi $\mathrm{pH}$ yang rendah berakibat terjadinya proses korosis sehingga menyebabkan larutnya besi dan logam. Pada sumur ketiga nilai besi (Fe) sebelum hujan sebesar 9,294 mg/l dan setelah hujan 0,306 mg/l. Tingginya nilai besi ( $\mathrm{Fe})$ pada lokasi ketiga ini dipengaruhi oleh kondisi tanah gambut dimana warna air cokelat kemerahan/kekuningan. Adanya ion besi menyebabkan air berwarna kemerahan/kekuningan (Sarwono, 2002). Pada sumur keempat nilai besi (Fe) sebelum hujan sebesar 7,69 mg/l dan setelah hujan 0,280 mg/l. Untuk sumur sebelum hujan kadar besi (Fe) di atas baku mutu kelas I. Hal ini di sebabkan struktur tanah pada lokasi keempat yang tergolong gambut sehingga dapat mempengaruhi 
aliran atau rembesan air tanah yang mengandung $\mathrm{Fe}$, karena kemungkinan rembesan air tanah tersebut tertahan / terhambat oleh serat serat dan akar-akar pohon yang terdapat pada tanah gambut (Najiyati, dkk 2005).

- $\mathrm{pH}$

$\mathrm{pH}$ atau derajat keasaman digunakan untuk menyatakan tingkat keasaaman atau basa yang dimiliki oleh suatu zat, larutan atau benda. $\mathrm{pH}$ normal memiliki nilai 7 sementara bila nilai $\mathrm{pH}>7$ menunjukkan zat tersebut memiliki sifat basa sedangkan nilai $\mathrm{pH}<7$ menunjukkan keasaman. Hasil pengujian kualitas air untuk parameter $\mathrm{pH}$ dapat dilihat pada Tabel 6 berikut :

Tabel 6. Hasil Analisa Kualitas Air Sumur Parameter pH

\begin{tabular}{|c|c|c|c|c|c|c|c|}
\hline \multirow{2}{*}{ No } & \multirow{2}{*}{ Sumur } & $\begin{array}{c}\text { PP No.82 } \\
\text { Tahun } 2001 \\
\end{array}$ & \multirow{2}{*}{ Satuan } & \multirow{2}{*}{$\begin{array}{c}\text { Sebelum } \\
\text { Hujan }\end{array}$} & \multirow[t]{2}{*}{ Ket } & \multirow{2}{*}{$\begin{array}{c}\text { Setelah } \\
\text { Hujan }\end{array}$} & \multirow[t]{2}{*}{ Ket } \\
\hline & & Kelas 1 & & & & & \\
\hline 1 & W2 & $6-9$ & $\mathrm{mg} / \mathrm{l}$ & 7,25 & Layak & 6,93 & Layak \\
\hline 2 & W4 & $6-9$ & $\mathrm{mg} / \mathrm{l}$ & 6,94 & Layak & 6,872 & Layak \\
\hline 3 & W7 & $6-9$ & $\mathrm{mg} / \mathrm{l}$ & 7,09 & Layak & 6,142 & Layak \\
\hline 4 & W10 & $6-9$ & $\mathrm{mg} / \mathrm{l}$ & 6,82 & Layak & 6,476 & Layak \\
\hline
\end{tabular}

Berdasarkan hasil pengujian untuk parameter $\mathrm{pH}$ keempat sumur berada dalam rentang 6-9 sesuai dengan klasifikasi mutu air menurut Peraturan Pemerintah Nomor 82 Tahun 2001 kelas I. Hasil ini menunjukkan bahwa $\mathrm{pH}$ di dalam air sumur tersebut sudah memenuhi standar baku mutu kualitas air. Air dengan pH lebih tinggi (basa) biasanya disebabkan adanya pencemaran natrium bikarbonat dan jika dikonsumsi bisa mengakibatkan penurunan pencernaan dan penyerapan mineral ransum, seperti kalsium, fosfor, magnesium dan kalium. Begitu juga sebaliknya air yang asam ( $\mathrm{pH}$ rendah) akan mengganggu kesehatan dan mempermudah infeksi parasit.

\section{- $\quad$ Sulfat $\left(\mathrm{SO}_{4}\right)$}

Sulfat secara luas terdistribusi di alam dan dalam air alam, terutama dalam air limbah industri. Salah satunya adalah air buangan limbah industri kertas dan pertambangan yang memiliki kadar sulfat yang tinggi karena oksidasi dari pirit. Konsentrasi sulfat di dalam air alam umumnya terdapat dalam jumlah yang sangat besar (Aprianti, 2008). Hasil pengujian kualitas air untuk parameter sulfat $\left(\mathrm{SO}_{4}\right)$ dapat dilihat pada Tabel 7 berikut :

Tabel 7. Hasil Analisa Kualitas Air Sumur Parameter Sulfat $\left(\mathrm{SO}_{4}\right)$

\begin{tabular}{|c|c|c|c|c|c|c|c|}
\hline \multirow{2}{*}{ No } & \multirow{2}{*}{ Sumur } & $\begin{array}{c}\text { PP No.82 } \\
\text { Tahun } 2001 \\
\end{array}$ & \multirow{2}{*}{ Satuan } & \multirow{2}{*}{$\begin{array}{c}\text { Sebelum } \\
\text { Hujan }\end{array}$} & \multirow[t]{2}{*}{ Ket } & \multirow{2}{*}{$\begin{array}{c}\text { Setelah } \\
\text { Hujan }\end{array}$} & \multirow[t]{2}{*}{ Ket } \\
\hline & & Kelas 1 & & & & & \\
\hline 1 & W2 & 400 & $\mathrm{mg} / \mathrm{l}$ & 0 & Layak & 77 & Layak \\
\hline 2 & W4 & 400 & $\mathrm{mg} / \mathrm{l}$ & 4 & Layak & 31 & Layak \\
\hline 3 & W7 & 400 & $\mathrm{mg} / \mathrm{l}$ & 4 & Layak & 44 & Layak \\
\hline 4 & W10 & 400 & $\mathrm{mg} / \mathrm{l}$ & 32 & Layak & 25 & Layak \\
\hline
\end{tabular}

Berdasarkan Hasil pengujian kualitas air sumur untuk parameter Sulfat (SO4) pada keempat sumur sebelum hujan dan setelah hujan memiliki kandungan sulfat dibawah baku 
mutu Peraturan Pemerintah Nomor 82 Tahun 2001 dan masuk kedalam klasifikasi kelas I. Dengan hasil ini sulfat ( $\mathrm{SO} 4$ ) yang terdapat pada air sumur yang berada di daerah penelitian masih aman untuk digunakan.

\section{- $\mathrm{BOD}_{5}$ (Biological Oxigen Demand)}

Kebutuhan oksigen biologis (BOD) merupakan jumlah oksigen yang diperlukan oleh mikroorganisme aerobik dalam proses penguraian senyawa organik (Effendi, 2003). Hasil pengujian kualitas air untuk parameter $\mathrm{BOD}_{5}$ (Biological Oxigen Demand) dapat dilihat pada Tabel 8 berikut :

Tabel 8. Hasil Analisa Kualitas Air Sumur Parameter $\mathrm{BOD}_{5}$ (Biological Oxigen Demand)

\begin{tabular}{|c|c|c|c|c|c|c|c|}
\hline \multirow[t]{2}{*}{ No } & \multirow[t]{2}{*}{ Sumur } & $\begin{array}{c}\text { PP No.82 } \\
\text { Tahun } \\
2001 \\
\end{array}$ & \multirow[t]{2}{*}{ Satuan } & \multirow[t]{2}{*}{$\begin{array}{l}\text { Sebelum } \\
\text { Hujan }\end{array}$} & \multirow[t]{2}{*}{ Ket } & \multirow[t]{2}{*}{$\begin{array}{c}\text { Setelah } \\
\text { Hujan }\end{array}$} & \multirow[t]{2}{*}{ Ket } \\
\hline & & Kelas 1 & & & & & \\
\hline 1 & W2 & 2 & $\mathrm{mg} / \mathrm{l}$ & 135,59 & Tidak Layak & 19,49 & Tidak Layak \\
\hline 2 & W4 & 2 & $\mathrm{mg} / \mathrm{l}$ & 17,28 & Tidak Layak & 12,2 & Tidak Layak \\
\hline 3 & W7 & 2 & $\mathrm{mg} / \mathrm{l}$ & 20,33 & Tidak Layak & 24,4 & Tidak Layak \\
\hline 4 & W10 & 2 & $\mathrm{mg} / \mathrm{l}$ & 118,64 & Tidak Layak & 24,91 & Tidak Layak \\
\hline
\end{tabular}

Berdasarkan hasil pengukuran BOD sebelum hujan terhadap semua sumur yang berada di Jalan Dr. Sutomo - Jalan Ampera memiliki kandungan BOD yang melebihi baku mutu menurut Peraturan Pemerintah Nomor 82 Tahun 2001. Pada sumur pertama nilai BOD yang tinggi sebesar 135,59 mg/l sebelum hujan dan 19,49 setelah hujan. Nilai ini menunjukkan bahwa nilai BOD pada sumur pertama di atas ambang batas. Hal ini disebabkan oleh jarak sumur dengan septic tank yang dekat sehingga memungkinkan limbah yang berasal dari septik tank tersebut masuk kedalam tanah dan meresap kembali ke dalam sumur yang meningkatkan kandungan bahan organik dalam air yang kemudian di uraikan oleh mikroorganisme sehingga meningkatkan nilai BOD dalam air. Untuk nilai BOD pada sumur kedua 17,28 mg/l sebelum hujan dan 12,2 $\mathrm{mg} / \mathrm{l}$ setelah hujan. Nilai BOD ini juga menunjukkan di atas ambang batas baku mutu kelas I yaitu $2 \mathrm{mg} / \mathrm{l}$. Nilai BOD pada sumur kedua ini disebabkan kurangnya perhatian masyarakat untuk menutup sumur dimana pada sumur kedua ini sumur terbuka dan hanya bertutupan papan-papan yang masih mempunyai celah untuk kotoran atau sampah-sampah masuk kedalam sumur. Pada sumur ketiga yaitu dengan nilai $20,33 \mathrm{mg} / \mathrm{l}$ sebelum hujan dan 24,4 setelah hujan. Untuk di lokasi ketiga ini merupakan daerah pemukiman sehingga terjadi aktivitas masyarakat seperti mandi, mencuci dan lain sebagainya. Selain itu di lokasi tersebut terdapat warung kopi dan makanan yang tempat pembuangan dan pencucian berada dekat lokasi sumur. Hal ini yang menyebabkan nilai BOD di sumur tersebut berada di ambang batas kelas I dimana limbah cair tersebut masuk kedalam tanah dan merembes masuk kedalam sumur. Sedangkan pada sumur keempat nilai BOD melebih baku mutu yaitu 118,64 mg/l sebelum hujan dan 24,91 mg/l setelah hujan. Nilai ini juga di atas ambang batas kelas I yaitu 2 $\mathrm{mg} / \mathrm{l}$. Hal ini dikarenakan pada sampel keempat, sumur warga terletak didekat aktivitas pasar dimana sampah-sampah pasar atau limbah cair dari pasar dibuang begitu saja. Permasalahan ini dapat menimbulkan tercemarnya sumur disekitar pasar tersebut karena air limbah pasar tersebut dapat meresap kedalam tanah dan mencemari sumur didekat pasar tersebut. 


\section{KESIMPULAN}

Berdasarkan penelitian yang telah dilakukan, maka dapat disimpulkan :

a. Berdasarkan hasil perhitungan di atas kuantitas air sebelum hujan debit minimum 0,003368 l/detik, debit maksimum 0,003645 l/detik, debit rata-rata 0,003506 l/detik. Kuantitas air setelah hujan debit minimum l/detik, debit maksimum 0,004062 l/detik, debit rata-rata 0,00368 I/detik, maka sesuai Keputusan Menteri Energi dan Sumber Daya Mineral Nomor 1451/10/MEM/2000, sumber air baku (sumur) di daerah Kota Baru, Kelurahan Kota Baru, Kecamatan Pontianak Selatan, Kota Pontianak, tepatnya di jalan Dr. Sutomo sampai jalan Ampera masuk dalam daerah dengan kategori kuantitas air kecil (debit air (Q) $<2 \mathrm{l} / \mathrm{det}$ ).

b. Berdasarkan hasil pengujian semua parameter dapat disimpulkan bahwa kualitas air sumur yang berada di di lokasi Kota Baru, Kelurahan Kota Baru, Kecamatan Pontianak Selatan, Kota Pontianak tepatnya, di jalan Dr. Sutomo sampai jalan Ampera tidak layak untuk gunakan karena masih ada parameter yang berada di atas baku mutu air Kelas I menurut PP No. 82 Tahun 2001.

\section{Ucapan Terima Kasih}

Penulis mengucapkan terima kasih kepada kedua orang tua yang telah memberikan dukungan secara moril dan materil. Terima kasih juga kepada Bapak Dr.Ir.Marsudi, MT dan Bapak Robby Irsan ST.,M.Si selaku dosen pembimbing dalam penelitian ini serta tidak lupa pula kepada teman-teman angkatan 2009 Fakultas Teknik UNTAN yang banyak membantu dalam penyelesaian skripsi ini.

\section{Referensi}

Aprianti, M. 2008. Analisis Kandungan Boron, Seng, Mangan dan Sulfat dalam Air Sungai Mesjid sebagai Air Baku PDAM Dumai. FMIPA-UR,Pekanbaru

Effendi, Hefni. 2003. Telaah Kualitas Air. Yogyakarta : Kanisius

Najiyati, S., Lili Muslihat dan I Nyoman N. Suryadiputra. 2005. Panduan pengelolaan lahan gambut untuk pertanian berkelanjutan. Proyek Climate Change, Forests and Peatlands in Indonesia. Wetlands International - Indonesia Programme dan Wildlife Habitat Canada. Bogor. Indonesia.

Peraturan Pemerintah Nomor 82 Tahun 2001. Pengelolaan Kualitas Air dan Pengendalian Pencemaran Air

Saeni, M. S. 1989. Kimia lingkungan. Pusat Antar Universitas. Ilmu Hayat. IPB. Bogor.

Hardjowigeno, H. Sarwono. 2002. IImu Tanah. Jakarta : Akademika Pressindo 